\title{
MICROWAVE ASSISTED SYNTHESIS, SPECTRAL CORRELATION AND ANTIMICROBIAL EVALUATION OF SOME ARYL IMINES
}

\author{
S PAZHINIVEL SAKTHINATHAN ${ }^{\prime}$, RAMAMOORTHY SURESH ${ }^{l}$, DAKSHNAMOORTHY KAMALAKKANNAN ${ }^{\prime}$, \\ VEERANDIRAN MALA ${ }^{1}$, KALIYAN SATHIYAMOORTHI ${ }^{1}$, GANESAN VANANGAMUDI ${ }^{1}$, AND GANESAMOORTHY \\ THIRUNARAYANAN ${ }^{2, *}$
}

${ }^{1} P G \&$ Research Department of Chemistry, Government Arts College, C-Mutlur, Chidambaram-608102

${ }^{2}$ Department of Chemistry, Annamalai University, Annamalainagar-608002, India.

\begin{abstract}
A series of aryl imines have been synthesized by $\mathrm{SiO}_{2}-\mathrm{H}_{3} \mathrm{PO}_{4}$ catalyzed microwave assisted condensation of amine and aldehyde under solvent-free conditions. The yield of the imines has been found to be more than $80 \%$. The purity of all imines has been checked using their physical constants and spectral data as published earlier in literature. The UV $\lambda_{\text {max }}(\mathrm{nm})$, infrared $\nu \mathrm{C}=\mathrm{N}\left(\mathrm{cm}^{-1}\right), \mathrm{NMR} \delta(\mathrm{ppm})$ of $\mathrm{C}-\mathrm{H}$ and $\mathrm{C}=\mathrm{N}$ spectral data have been correlated with Hammett substituent constants and $\mathrm{F}$ and $\mathrm{R}$ parameters using single and multi-linear regression analysis. From the results of statistical analysis, the effect of substituents on the above spectral data has been studied. The antimicrobial activities of all imines have been studied using Bauer-Kirby method.
\end{abstract}

Key words: Solvent-free synthesis, $\mathrm{SiO}_{2}-\mathrm{H}_{3} \mathrm{PO}_{4}$, Aryl imines, IR and NMR spectra, Spectral correlation study, Antimicrobial activities

\section{INTRODUCTION}

The Schiff's bases are bimolecular condensation products of primary amine with carbonyl compound. They are generally known as azomethines possess $(-\mathrm{C}=\mathrm{N}-)$ to honor Hugo Schiff's, who had synthesized such compounds earlier. Schiff's bases are characterized by the $-\mathrm{N}=\mathrm{CH}-$ (imine) group which finds importance in elucidating the mechanism of transamination and racemization reactions in biological systems ${ }^{1}$. Schiff's bases of aliphatic aldehydes are relatively unstable which readily undergo polymerization while those of aromatic aldehydes having an effective conjugation system are found to be more stable. Schiff's bases have been reported to play very importan role in many biological and chemical reactions, due to the presence of the imine linkage. Schiff's bases are generally Bi- or tri- dentate ligands capable of forming very stable complexes with transition metals ${ }^{2}$. Schiff's bases, derived from aromatic amines and aromatic aldehydes are reported to be involved in the study of asymmetric catalysis ${ }^{3}$, agnetic properties ${ }^{4}$, photochromism ${ }^{5}$, binding with $\mathrm{DNA}^{6}$, construction of supra molecular structures ${ }^{7}$, the study of activity against Ehrlichascites carcinoma (EAC) ${ }^{8}$ the field of dyes and pigments ${ }^{9}$, the development of corrosion inhibitors ${ }^{10}$, anti-HIV ${ }^{11}$ and in the evaluation of physical properties in the crystalline state ${ }^{12}$. Optically active imine derivatives possess multipronged biological activities such as antimicrobial ${ }^{13}$, anticancer ${ }^{14}$ anti-tubularcular ${ }^{15-17}$, nematicidal-insecticidal ${ }^{18}$, anti-inflammatory and lipoxygenas ${ }^{19}$. The imine moieties are important intermediates and versatile starting materials for the synthesis of chiral amines ${ }^{20}$, pyrimidine derivatives ${ }^{21}$, phenylhydrazones ${ }^{22}$, Mannich bases ${ }^{23}$, indoles ${ }^{24}$, quinoxalines ${ }^{25}$, imidazoles ${ }^{26}$ $\alpha$-ethoxycarbomates ${ }^{27}$, aminotriphenylmethanes ${ }^{28}$, Michael adducts ${ }^{29}$, allyl products $^{30}$, optically active $\alpha$-alkyl aldehydes ${ }^{31}$ by hydrogenation ${ }^{32}$, nucleophilic addition with organometallics ${ }^{33}$ and cycloaddition reaction ${ }^{34}$. Many reagents have been used for the synthesis of optically active imines such as Lewis acids ${ }^{35}$, molecular sieves in ionic liquids ${ }^{36}$, solid super acids, K-10 montmorillonite ${ }^{37}$, Tandam catalysts ${ }^{38}, \mathrm{MnO}_{2}{ }^{39}, \mathrm{CaO}^{40}, \mathrm{ZnCl}_{2}{ }^{20}, \mathrm{MgSO}_{4}-\mathrm{PPTS}{ }^{22}$, alumina ${ }^{41}$ $\mathrm{Ti}(\mathrm{OR})_{4}^{42}, \mathrm{CuCl}_{2}^{43}, \mathrm{MCM}-41-\mathrm{SO}_{3}$ nanocatalyst ${ }^{44}, \quad \mathrm{P}_{2} \mathrm{O}_{5}-\mathrm{SiO}_{2}{ }^{45}$ promoted by microwave irradiation ${ }^{39}$, Cinchona alkaloid-thiourea ${ }^{46}$, Infrared ${ }^{47}$ and ultrasound radiation ${ }^{48}$. These catalysts have been applied for the synthesis of chiral amines by oxidative coupling of amines ${ }^{49,50}$ with carbonyl compounds ${ }^{17}$, ${ }^{37,38}$ alcohols ${ }^{30}$ and acid chlorides ${ }^{33,35}$. The microwave assisted synthesis has become popular in academic and pharmaceutical areas since this involves a new enabling technology for developing new drugs. Chemists and scientists ${ }^{17}$ ${ }^{37,51}$ prefer solvent-free microwave synthetic methods for synthesizing organic compounds, since they involve shorter duration, operational simplicity, easy workup procedure, less hazardousness to humans and environment and better yields. No report has been found in the literature regarding the synthesis of imines with $\mathrm{SiO}_{2}-\mathrm{H}_{3} \mathrm{PO}_{4}$ catalyst under microwave assistance and spectral as well as biological activities of imines. Therefore the authors have taken efforts to synthesis of imines from amine and carbonyl compound using $\mathrm{SiO}_{2}-\mathrm{H}_{3} \mathrm{PO}_{4}$ catalyst with microwave irradiation under solvent-free conditions. The various spectral data of these imines have been utilized for studying the quantitative structure activity relationships through Hammett correlations. The biological activities of these imine derivatives have been studied with the help of standard ${ }^{52}$ method.

\section{EXPERIMENTAL}

General

All the chemicals involved in the present investigation, have been procured from Sigma-Aldrich and E-Merck chemical company. Melting points of all imines have been determined in open glass capillaries on SUNTEX melting point apparatus and are uncorrected. The UV spectra of all synthesized imines have been recorded withELICO-BL222 spectrophotometer $(\lambda \mathrm{nm})$ in spectral grade methanol solvent. Infrared spectra $\left(\mathrm{KBr}, 4000-400 \mathrm{~cm}^{-1}\right)$ have been recorded on AVATAR-300 Fourier transform spectrophotometer. Bruker AV400 NMR spectrometer operating at $400 \mathrm{MHz}$ has been utilized for recording ${ }^{1} \mathrm{H}$ NMR spectra and $100 \mathrm{MHz}$ for ${ }^{13} \mathrm{C}$ spectra in $\mathrm{CDCl}_{3}$ solvent using TMS as internal standard.

General procedure for synthesis of substituted benzylidene-2-chloro4-methyl aniline

Appropriate quantities of aryl amine $(2 \mathrm{mmol})$, substituted benzaldehydes $(2 \mathrm{mmol})$ and $\mathrm{SiO}_{2}-\mathrm{H}_{3} \mathrm{PO}_{4}^{53}(0.5 \mathrm{~g})$ have been taken in borosil tube and tightly capped. The mixture has been subjected to microwave irradiation for 6-12 minutes in a microwave oven (Scheme-1) (LG Grill, Intellowave, Microwave Oven, $160-800 \mathrm{~W})$ and then cooled to room temperature. After separating the organic layer with dichloromethane the solid product has been obtained on evaporation. The solid, on recrystallization with benzene-hexane mixture gives glittering product. The insoluble catalyst has been recycled by washing with ethyl acetate $(8 \mathrm{~mL})$ followed by drying in an oven at $100^{\circ} \mathrm{C}$ for $1 \mathrm{~h}$ and reused for further reactions

\section{RESULTS AND DISCUSSION}

\section{Spectral linearity}

Spectral linearity of synthesized imines has been studied by evaluating the substituent effects on the spectral frequencies. The spectral data observed for the imines, UV $\lambda \max (\mathrm{nm})$, infrared $v \mathrm{C}=\mathrm{N}$, the proton chemical shifts $\delta(\mathrm{ppm})$, of $\mathrm{C}-\mathrm{H}$ and carbon chemical shifts of $\mathrm{C}=\mathrm{N}$ are correlated with various substituent constants.

UV-Vis spectral study

The measured absorption maxima $\left(\lambda_{\max } \mathrm{nm}\right)$ of synthesized imines are presented in Table-1. These values have been correlated with Hammett substituent constants and $\mathrm{F}$ and $\mathrm{R}$ parameters using single and multi-linear regression analyses ${ }^{54-56}$. Hammett equation employed, for the correlation analysis, involving the absorption maxima is as shown below in equation (1).

$$
\lambda=\rho \sigma+\lambda_{\mathrm{o}}
$$


where $\lambda$ is the frequency for the parent member of the series.

The results of statistical analysis of these values with Hammett substituent constants are presented in Table-2. From Table-2, it is observed that the UV $\lambda_{\max }(\mathrm{nm})$ values of all aryl imines have shown satisfactory correlation with Hammett substituent constant $\sigma^{+}(\mathrm{r}=0.958)$. The UV $\lambda \quad(\mathrm{nm})$ values of all aryl imines have shown poor correlations $(\mathrm{r}<0.900)$ with the remaining Hammett substituent constants namely $\sigma, \sigma_{\mathrm{I}}$ and $\sigma_{\mathrm{R}}$ and $F$ and $R$ parameters. This is at- tributed to the weak inductive, field and resonance effects of the substituents for predicting the reactivity on the UV absorption through resonance as per the conjugative structure as shown in Fig-1. All the correlations have shown negative $\rho$ values. This indicates the operation of reverse substituent effect with respect to $U V \lambda_{\max }(\mathrm{nm})$ in all aryl imines. The multi regression analysis of these UV spectral data of all imines with inductive, resonance and Swain - Lupton's parameter ${ }^{57}$ produce satisfactory correlations as shown in equations (2) and (3).

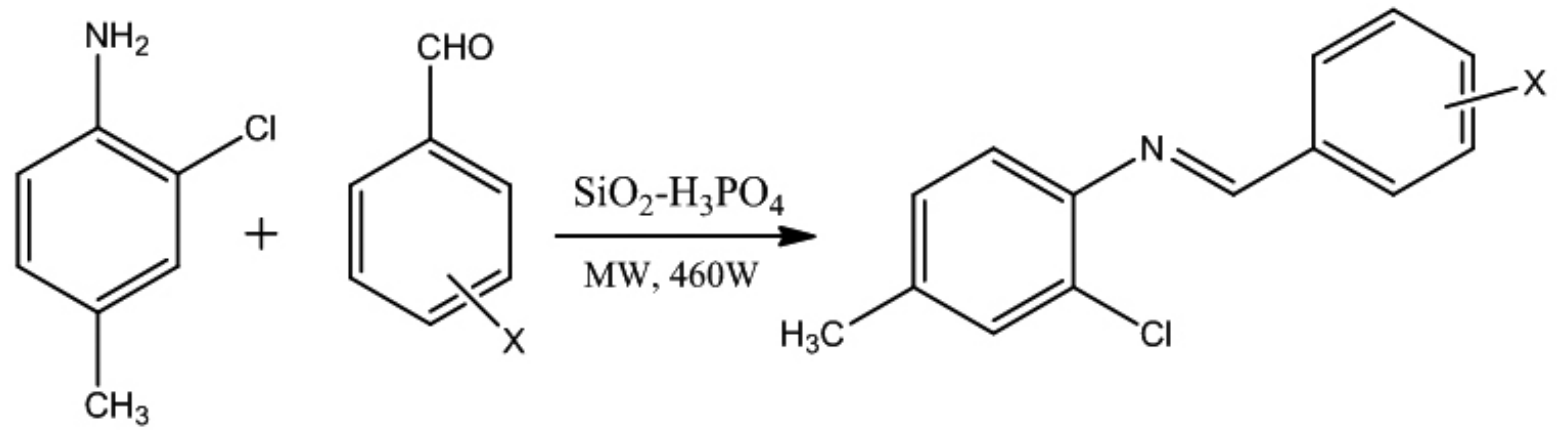

\section{$\mathrm{X}=\mathrm{H}$, 4-Br, 2-Cl, 3-Cl, 4-Cl, 2-F, 4-Me, 2-OMe, 4-OMe, 4- $\mathrm{NO}_{2}$}

Scheme-1. Synthesis of aryl imines from aryl amine and aryl aldehydes in the presence of $\mathrm{SiO}_{2}-\mathrm{H}_{3} \mathrm{PO}_{4}$ catalyst under microwave irradiation.

Table-1. The Physical Constants, UV, IR and NMR spectroscopic data of substituted benzylidene-2-chloro-4-methylanilines .

\begin{tabular}{|c|c|c|c|c|c|c|c|c|c|}
\hline \multirow{2}{*}{ S.No } & \multirow{2}{*}{ Substituent } & \multirow{2}{*}{ M.W. } & \multirow{2}{*}{$\begin{array}{l}\text { Yield } \\
(\%)\end{array}$} & \multirow{2}{*}{ M.p. $\left({ }^{\circ} \mathrm{C}\right)$} & \multirow{2}{*}{$\begin{array}{c}\mathrm{UV} \\
\lambda \max \end{array}$} & \multirow{2}{*}{$\begin{array}{l}\mathrm{IR} v \mathrm{C}=\mathrm{N} \\
\left(\mathrm{cm}^{-1}\right)\end{array}$} & \multicolumn{2}{|c|}{ NMR(ppm) } & \multirow{2}{*}{$\operatorname{Mass}(\mathrm{m} / \mathrm{z})$} \\
\hline & & & & & & & $\delta^{1} \mathrm{H}(\mathrm{CH}=\mathrm{N})$ & $\delta^{13} \mathrm{C}(\mathrm{C}=\mathrm{N})$ & \\
\hline 1 & $\mathrm{H}$ & 230 & 90 & $120-121$ & 242.0 & 1628.87 & 8.131 & 160.25 & $\begin{array}{c}230\left[\mathrm{M}^{+}\right], 214,194,152,139,125,104,90 \\
, 77,34,15\end{array}$ \\
\hline 2 & $4-\mathrm{Br}$ & 309 & 92 & $70-71$ & 270.5 & 1581.79 & 8.278 & 161.35 & $\begin{array}{c}309\left[\mathrm{M}^{+}\right], 313\left[\mathrm{M}^{+}\right], 91,272,228,181 \\
167,154,139,125,78,34,15\end{array}$ \\
\hline 3 & $2-\mathrm{Cl}$ & 264 & 88 & $64-65$ & 262.5 & 1622.15 & 8.796 & 157.04 & $\begin{array}{c}264\left[\mathrm{M}^{+}\right], 266\left[\mathrm{M}^{+}\right], 248,228,152,139 \\
138,125,124,111,34,15\end{array}$ \\
\hline 4 & $3-\mathrm{Cl}$ & 264 & 85 & $52-53$ & 260.5 & 1632.23 & 8.281 & 158.72 & $\begin{array}{c}264\left[\mathrm{M}^{+}\right], 266\left[\mathrm{M}^{+}\right], 248,228,152,139 \\
138,125,124,111,34,15\end{array}$ \\
\hline 5 & $4-\mathrm{NO}_{2}$ & 264 & 90 & $65-66$ & 268.0 & 1612.24 & 8.294 & 158.86 & $\begin{array}{c}264\left[\mathrm{M}^{+}\right], 266\left[\mathrm{M}^{+}\right], 248,228,152,139 \\
138,125,124,111,34,15\end{array}$ \\
\hline 6 & $2-\mathrm{F}$ & 248 & 86 & $60-61$ & 248.5 & 1632.23 & 8.654 & 164.17 & $\begin{array}{c}248\left[\mathrm{M}^{+}\right], 250\left[\mathrm{M}^{+}\right], 228,212,202,152 \\
139,125,122,108,95,34,18,15 .\end{array}$ \\
\hline 7 & 4- $\mathrm{CH}_{3}$ & 244 & 92 & $62-63$ & 269.0 & 1622.14 & 8.28 & 160.3 & $\begin{array}{c}244\left[\mathrm{M}^{+}\right], 246\left[\mathrm{M}^{+}\right], 228,225,208,152 \\
139,118,104,91,34,15\end{array}$ \\
\hline 8 & $3-\mathrm{OCH}_{3}$ & 260 & 82 & $68-69$ & 283.5 & 1635.59 & 8.281 & 159.55 & $\begin{array}{c}260\left[\mathrm{M}^{+}\right], 262\left[\mathrm{M}^{+}\right], 244,228,224,152 \\
139,134,125,120,107,34,31,15 .\end{array}$ \\
\hline 9 & $4-\mathrm{OCH}_{3}$ & 260 & 84 & $58-59$ & 284.5 & 1632.23 & 8.245 & 162.41 & $\begin{array}{c}260\left[\mathrm{M}^{+}\right], 262\left[\mathrm{M}^{+}\right], 244,228,224,152 \\
139,134,125,120,107,34,31,15 .\end{array}$ \\
\hline 10 & $4-\mathrm{Cl}$ & 275 & 89 & $152-153$ & 265.5 & 1632.23 & 8.441 & 157.58 & $\begin{array}{c}275\left[\mathrm{M}^{+}\right], 259,239,228,152,149,139,135 \\
, 125,122,45,3,15 .\end{array}$ \\
\hline
\end{tabular}


Table-2. Results of statistical analysis of $\mathrm{UV} \lambda \max (\mathrm{nm}), v \mathrm{C}=\mathrm{N}\left(\mathrm{cm}^{-1}\right) \mathrm{IR}$, NMR $\delta^{1} \mathrm{H}(\mathrm{ppm}) \mathrm{CH}=\mathrm{N}$ and $\delta^{13} \mathrm{C}(\mathrm{ppm}) \mathrm{C}=\mathrm{N}$ of substituted benzylidene-2-chloro4-methylanilines with Hammett substituent constants $\sigma, \sigma^{+}, \sigma_{\mathrm{I}}, \sigma_{\mathrm{R}}, \mathrm{F}$ and $\mathrm{R}$ parameters.

\begin{tabular}{|c|c|c|c|c|c|c|c|}
\hline Frequency & Constants & $\mathrm{r}$ & I & $\rho$ & s & $\mathrm{n}$ & Correlated derivatives \\
\hline \multirow[t]{6}{*}{$\lambda \max (\mathrm{nm})$} & $\sigma$ & 0.855 & 267.49 & -17.78 & 12.69 & 10 & $\mathrm{H}, 4-\mathrm{Br}, 2-\mathrm{Cl}, 3-\mathrm{Cl}, 4-\mathrm{Cl}, 2-\mathrm{F}, 4-\mathrm{Me}, 2-\mathrm{OMe}, 4-\mathrm{OMe}, 4-\mathrm{NO}_{2}$ \\
\hline & $\sigma^{+}$ & 0.958 & 267.15 & -15.89 & 11.47 & 9 & 4-Br, 2-Cl, 3-Cl, 4-Cl, 2-F, 4-Me, 2-OMe, 4-OMe, 4- $\mathrm{NO}_{2}$ \\
\hline & $\sigma \mathrm{I}$ & 0.806 & 263.98 & 4.14 & 14.12 & 10 & $\mathrm{H}, 4-\mathrm{Br}, 2-\mathrm{Cl}, 3-\mathrm{Cl}, 4-\mathrm{Cl}, 2-\mathrm{F}, 4-\mathrm{Me}, 2-\mathrm{OMe}, 4-\mathrm{OMe}, 4-\mathrm{NO}_{2}$ \\
\hline & $\sigma \mathrm{R}$ & 0.833 & 260.31 & -23.25 & 13.03 & 10 & $\mathrm{H}, 4-\mathrm{Br}, 2-\mathrm{Cl}, 3-\mathrm{Cl}, 4-\mathrm{Cl}, 2-\mathrm{F}, 4-\mathrm{Me}, 2-\mathrm{OMe}, 4-\mathrm{OMe}, 4-\mathrm{NO}_{2}$ \\
\hline & $\mathrm{F}$ & 0.805 & 266.67 & -3.32 & 14.13 & 10 & $\mathrm{H}, 4-\mathrm{Br}, 2-\mathrm{Cl}, 3-\mathrm{Cl}, 4-\mathrm{Cl}, 2-\mathrm{F}, 4-\mathrm{Me}, 2-\mathrm{OMe}, 4-\mathrm{OMe}, 4-\mathrm{NO}_{2}$ \\
\hline & $\mathrm{R}$ & 0.833 & 259.98 & -21 & 13.08 & 10 & $\mathrm{H}, 4-\mathrm{Br}, 2-\mathrm{Cl}, 3-\mathrm{Cl}$, 4-Cl, 2-F, 4-Me, 2-OMe, 4-OMe, 4- $\mathrm{NO}_{2}$ \\
\hline \multirow[t]{6}{*}{$v \mathrm{C}=\mathrm{N}$} & $\sigma$ & 0.815 & 1624 & -7.22 & 16.94 & 10 & $\mathrm{H}, 4-\mathrm{Br}, 2-\mathrm{Cl}, 3-\mathrm{Cl}$, 4-Cl, 2-F, 4-Me, 2-OMe, 4-OMe, 4- $\mathrm{NO}_{2}$ \\
\hline & $\sigma^{+}$ & 0.812 & 1623.9 & -7.31 & 16.7 & 10 & $\mathrm{H}, 4-\mathrm{Br}, 2-\mathrm{Cl}, 3-\mathrm{Cl}, 4-\mathrm{Cl}, 2-\mathrm{F}, 4-\mathrm{Me}, 2-\mathrm{OMe}, 4-\mathrm{OMe}, 4-\mathrm{NO}_{2}$ \\
\hline & $\sigma \mathrm{I}$ & 0.812 & 1626.4 & -9.26 & 16.99 & 10 & $\mathrm{H}, 4-\mathrm{Br}, 2-\mathrm{Cl}, 3-\mathrm{Cl}, 4-\mathrm{Cl}, 2-\mathrm{F}, 4-\mathrm{Me}, 2-\mathrm{OMe}, 4-\mathrm{OMe}, 4-\mathrm{NO}_{2}$ \\
\hline & $\sigma \mathrm{R}$ & 0.722 & 1619.6 & -15.99 & 16.7 & 10 & $\mathrm{H}, 4-\mathrm{Br}, 2-\mathrm{Cl}, 3-\mathrm{Cl}$, 4-Cl, 2-F, 4-Me, 2-OMe, 4-OMe, 4- $\mathrm{NO}_{2}$ \\
\hline & $\mathrm{F}$ & 0.802 & 1623.9 & -2.03 & 17.12 & 10 & $\mathrm{H}, 4-\mathrm{Br}, 2-\mathrm{Cl}, 3-\mathrm{Cl}$, 4-Cl, 2-F, 4-Me, 2-OMe, 4-OMe, 4- $\mathrm{NO}_{2}$ \\
\hline & $\mathrm{R}$ & 0.715 & 1620 & -12 & 16.85 & 10 & $\mathrm{H}, 4-\mathrm{Br}, 2-\mathrm{Cl}, 3-\mathrm{Cl}, 4-\mathrm{Cl}, 2-\mathrm{F}, 4-\mathrm{Me}, 2-\mathrm{OMe}, 4-\mathrm{OMe}, 4-\mathrm{NO}_{2}$ \\
\hline \multirow[t]{6}{*}{$\delta \mathrm{CH}=\mathrm{N}$} & $\sigma$ & 0.804 & 8.42 & -0.03 & 0.25 & 10 & $\mathrm{H}, 4-\mathrm{Br}, 2-\mathrm{Cl}, 3-\mathrm{Cl}, 4-\mathrm{Cl}, 2-\mathrm{F}, 4-\mathrm{Me}, 2-\mathrm{OMe}, 4-\mathrm{OMe}, 4-\mathrm{NO}_{2}$ \\
\hline & $\sigma^{+}$ & 0.818 & 8.41 & 0.09 & 0.25 & 10 & $\mathrm{H}, 4-\mathrm{Br}, 2-\mathrm{Cl}, 3-\mathrm{Cl}, 4-\mathrm{Cl}, 2-\mathrm{F}, 4-\mathrm{Me}, 2-\mathrm{OMe}, 4-\mathrm{OMe}, 4-\mathrm{NO}_{2}$ \\
\hline & $\sigma \mathrm{I}$ & 0.863 & 8.27 & 0.43 & 0.23 & 10 & $\mathrm{H}, 4-\mathrm{Br}, 2-\mathrm{Cl}, 3-\mathrm{Cl}$, 4-Cl, 2-F, 4-Me, 2-OMe, 4-OMe, 4- $\mathrm{NO}_{2}$ \\
\hline & $\sigma \mathrm{R}$ & 0.954 & 8.28 & -0.58 & 0.21 & 9 & H, 4-Br, 2-Cl, 3-Cl, 4-Cl, 2-F, 4-Me, 2-OMe, 4-OMe \\
\hline & $\mathrm{F}$ & 0.844 & 8.25 & 0.45 & 0.23 & 10 & $\mathrm{H}, 4-\mathrm{Br}, 2-\mathrm{Cl}, 3-\mathrm{Cl}, 4-\mathrm{Cl}, 2-\mathrm{F}, 4-\mathrm{Me}, 2-\mathrm{OMe}, 4-\mathrm{OMe}, 4-\mathrm{NO}_{2}$ \\
\hline & $\mathrm{R}$ & 0.844 & 8.31 & -0.42 & 0.23 & 10 & $\mathrm{H}, 4-\mathrm{Br}, 2-\mathrm{Cl}, 3-\mathrm{Cl}, 4-\mathrm{Cl}, 2-\mathrm{F}, 4-\mathrm{Me}, 2-\mathrm{OMe}$, 4-OMe, 4- $\mathrm{NO}_{2}$ \\
\hline \multirow[t]{6}{*}{$\delta \mathrm{C}=\mathrm{N}$} & $\sigma$ & 0.814 & 160.13 & -2.96 & 2.25 & 10 & $\mathrm{H}, 4-\mathrm{Br}, 2-\mathrm{Cl}, 3-\mathrm{Cl}$, 4-Cl, 2-F, 4-Me, 2-OMe, 4-OMe, 4- $\mathrm{NO}_{2}$ \\
\hline & $\sigma^{+}$ & 0.938 & 159.98 & -1.84 & 2.29 & 9 & $\mathrm{H}, 4-\mathrm{Br}, 2-\mathrm{Cl}, 3-\mathrm{Cl}, 4-\mathrm{Cl}, 4-\mathrm{Me}, 2-\mathrm{OMe}, 4-\mathrm{OMe}, 4-\mathrm{NO}_{2}$ \\
\hline & $\sigma \mathrm{I}$ & 0.94 & 161.27 & -4.19 & 2.27 & 9 & $\mathrm{H}, 4-\mathrm{Br}, 2-\mathrm{Cl}, 3-\mathrm{Cl}, 4-\mathrm{Cl}, 4-\mathrm{Me}, 2-\mathrm{OMe}, 4-\mathrm{OMe}, 4-\mathrm{NO}_{2}$ \\
\hline & $\sigma \mathrm{R}$ & 0.841 & 158.77 & -4.59 & 2.23 & 10 & $\mathrm{H}, 4-\mathrm{Br}, 2-\mathrm{Cl}, 3-\mathrm{Cl}, 4-\mathrm{Cl}, 2-\mathrm{F}, 4-\mathrm{Me}, 2-\mathrm{OMe}, 4-\mathrm{OMe}, 4-\mathrm{NO}_{2}$ \\
\hline & $\mathrm{F}$ & 0.809 & 160.14 & -0.96 & 2.47 & 10 & $\mathrm{H}, 4-\mathrm{Br}, 2-\mathrm{Cl}, 3-\mathrm{Cl}$, 4-Cl, 2-F, 4-Me, 2-OMe, 4-OMe, 4- $\mathrm{NO}_{2}$ \\
\hline & $\mathrm{R}$ & 0.855 & 158.41 & -5.32 & 2.07 & 10 & $\mathrm{H}, 4-\mathrm{Br}, 2-\mathrm{Cl}, 3-\mathrm{Cl}, 4-\mathrm{Cl}, 2-\mathrm{F}, 4-\mathrm{Me}, 2-\mathrm{OMe}, 4-\mathrm{OMe}, 4-\mathrm{NO}_{2}$ \\
\hline
\end{tabular}

$\mathrm{r}=$ correlation co-efficient $; \rho=$ slope $\mathrm{I}=$ intercept $\mathrm{s}=$ standard deviation $; \mathrm{n}=$ number of substituents.<smiles>C[O+]=C1C=CC(=CNc2ccc(C)cc2Cl)C=C1</smiles>

Fig-1. The resonance conjugative-structure.

$\lambda \max { }^{(\mathrm{mm})}=258.84( \pm 9.71)+4.15( \pm 1.25) \sigma_{\mathrm{I}}-23.26( \pm 5.69) \sigma_{\mathrm{R}}{ }^{---}(2)$ $(R=0.936, \quad \mathrm{n}=10, \quad \mathrm{P}>90 \%)$

$\lambda \max ^{(\mathrm{nm})}=262.25( \pm 9.24)-6.88( \pm 1.68) \mathrm{F}-22.06( \pm 3.21) \mathrm{R}---(3)$ $(R=0.940, \quad \mathrm{n}=10, \quad \mathrm{P}>90 \%)$

\section{IR Spectral study}

The infrared $\mathrm{vC}=\mathrm{N}$ stretching frequencies $\left(\mathrm{cm}^{-1}\right)$ of the synthesized imines have been recorded and presented in Table-1. These spectral data are correlated with Hammett substituent constants and Swain-Lupoton's parameters. In this correlation the structure parameter Hammett equation employed is as shown in equation (4).

$$
v=\rho \sigma+v_{0}
$$

where $v_{0}$ is the frequency for the parent member of the series.

The observed $v \mathrm{C}=\mathrm{N}$ stretching frequencies $\left(\mathrm{cm}^{-1}\right)$ are correlated with various Hammett substituent constants ${ }^{54-56}$ and $\mathrm{F}$ and $\mathrm{R}$ parameters through single and multi-regression analyses including Swain-Lupoton's parameters [57] The results of statistical analysis of single parameter correlation are shown in Table-2. From Table-2, it is observed that the infrared stretching frequency $v \mathrm{C}=\mathrm{N}\left(\mathrm{cm}^{-1}\right)$ values of all the aryl imines have shown poor correlations $(\mathrm{r}<$ 0.900 ) with all Hammett substituent constants and $F$ and $R$ parameters with negative $\rho$ value. This is due to the absence of polar, field and inductive effects of the substituents and hence they are unable to predict the reactivity on $\mathrm{C}=\mathrm{N}$ stretches. This is associated with the conjugative structure shown in Fig-4.

The single parameter correlations of $v \mathrm{C}=\mathrm{N}\left(\mathrm{cm}^{-1}\right)$ frequencies with Hammett substituent constants are fail in correlation. So, the authors think that it is worthwhile to seek the multi regression analysis which may produce a satisfactory correlation with inductive, resonance and Swain-Lupoton's constants. This is shown in the following equations (5) and (6).

$v \mathrm{C}=\mathrm{N}\left(\mathrm{cm}^{-1}\right)=1622.91( \pm 12.37)-9.25( \pm 2.43) \sigma_{\mathrm{I}}-15.99( \pm 3.37) \sigma_{\mathrm{R}}^{---}(5)$ $(R=0.925, \quad \mathrm{n}=10, \quad \mathrm{P}>90 \%)$ $v \mathrm{C}=\mathrm{N}\left(\mathrm{cm}^{-1}\right)=1621.38( \pm 11.99)-4.04( \pm 1.54) \mathrm{F}-12.62( \pm 2.92) \mathrm{R}---(6)$ $(R=0.952, \quad \mathrm{n}=10, \quad \mathrm{P}>95 \%)$ 


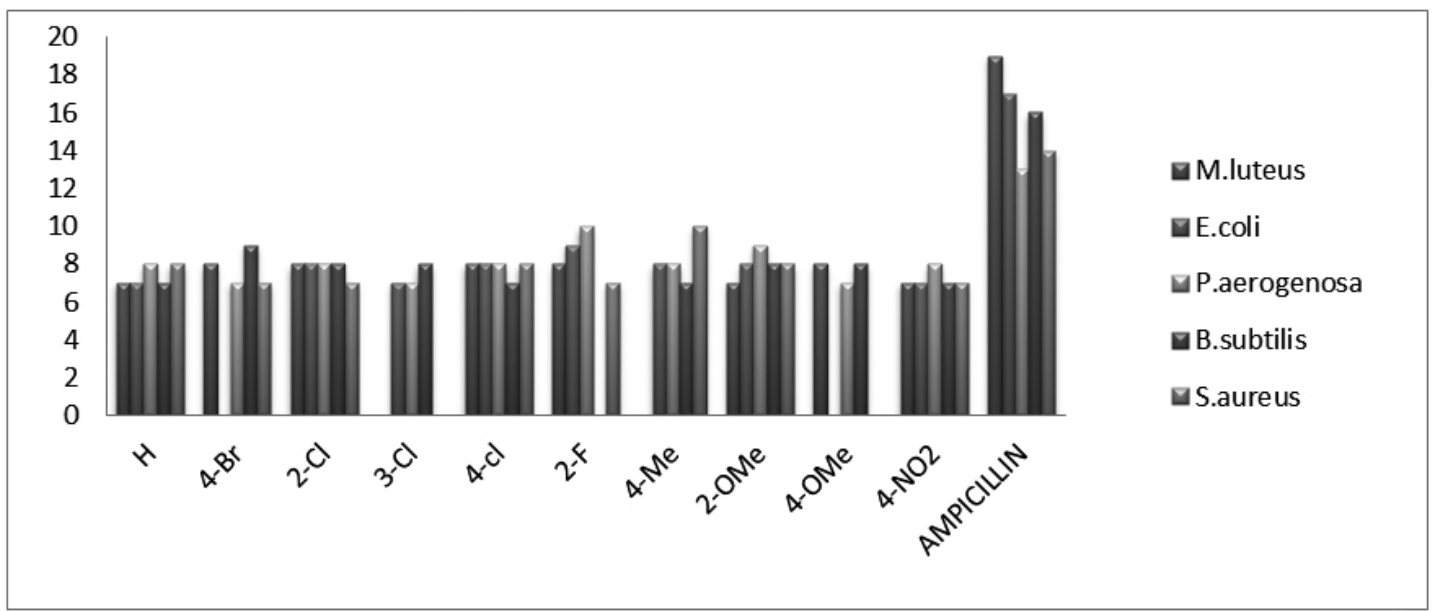

Fig-2. The antibacterial activities of substituted Benzylidene-2-chloro-4-methylanilines-clustered column chart.

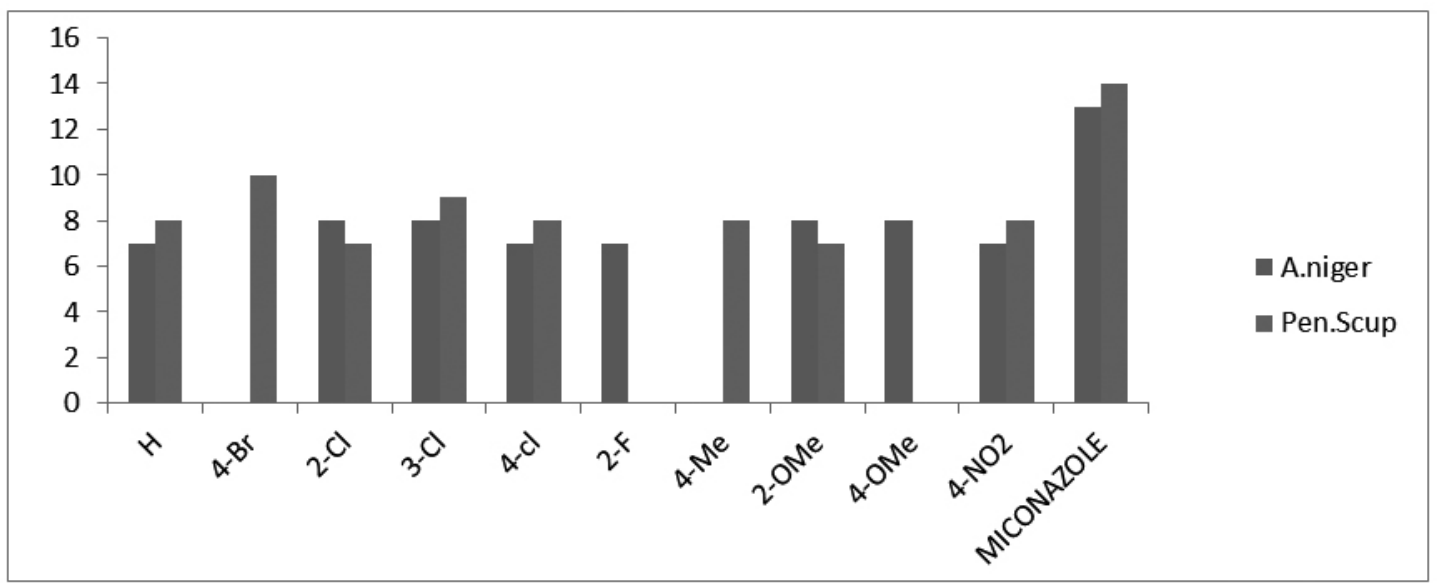

Fig-3. Antifungal activity of substituted Benzylidene-2-chloro-4-methylaniline-clustered column chart.

${ }^{1} \mathrm{H}$ NMR Spectral study

The ${ }^{1} \mathrm{H}$ NMR spectra of the imine derivatives under investigation have been recorded in deuteriochloroform solution employing tetramethylsilane (TMS) as internal standard. The signals of the iminic proton have been assigned and are presented in Table-1 (Supplementary data Table: S1).

In nuclear magnetic resonance spectra, the ${ }^{1} \mathrm{H}$ or the ${ }^{13} \mathrm{C}$ chemical shifts $(\delta \mathrm{ppm})$ depend on the electronic environment of the nuclei concerned. These chemical shifts have been correlated with reactivity parameters. Thus the Hammett equation has been used in the form as shown in (7).

$\log \delta=\log \delta_{0}+\rho \sigma$

Where $\delta_{0}$ is the chemical shift of the corresponding parent compound.

The assigned proton chemical shifts (ppm) of imines have been correlatedwith various Hammett sigma constants ${ }^{54-56}, \mathrm{~F}$ and $\mathrm{R}$ parameters. The results of statistical analysis are presented in Table-2.

From Table-2, it is observed that the ${ }^{1} \mathrm{H}$ NMR chemical shift $\delta \mathrm{CH}=\mathrm{N}(\mathrm{ppm})$ values have shown satisfactory correlation with Hammett substituent constant $\sigma_{\mathrm{I}}(\mathrm{r}=0.954)$. The ${ }^{1} \mathrm{H}$ NMR chemical shift $\delta \mathrm{CH}=\mathrm{N}(\mathrm{ppm})$ values of all aryl imines, have shown poor correlations $(\mathrm{r}<0.900)$ with the remaining Hammett substituent constants namely $\sigma, \sigma^{+}, \sigma_{\mathrm{R}}$ and $F \& R$ parameters. This is attributed to the weak polar, inductive and field effects of the substituents for predicting the reactivity on the ${ }^{1} \mathrm{H}$ NMR chemical shift through resonance as per conjugative structure as shown in Fig-1. In view of the inability of some of the Hammett $\sigma$ constants to produce individually satisfactory correlations, the authors think that, it is worthwhile to seek multiple correlations which produce satisfactory correlations as shown in the following equations (8) and (9). $\delta \mathrm{CH}=\mathrm{N}(\mathrm{ppm})=8.14( \pm 0.14)+0.43( \pm 0.09) \sigma_{\mathrm{I}}-0.58( \pm 0.09) \sigma_{\mathrm{R}}$ $(R=0.967, \quad \mathrm{n}=10, \quad \mathrm{P}>95 \%)$ $\delta \mathrm{CH}=\mathrm{N}(\mathrm{ppm})=8.18( \pm 0.15)+0.39( \pm 0.12) \mathrm{F}-0.37( \pm 0.11) \mathrm{R}$ $(R=0.957, \quad \mathrm{n}=10, \quad \mathrm{P}>95 \%)$

\section{${ }^{13}$ C NMR spectra}

In the present study, the chemical shifts (ppm) of imine $\mathrm{C}=\mathrm{N}$ carbon, have been assigned and are presented in Table-1 (Supplementary data Table: S2). Attempts have been made to correlate the $\delta \mathrm{C}=\mathrm{N}$ chemical shifts (ppm) with Hammett substituent constants, field and resonance parameters, with the help of single and multi-regression analyses to study the reactivity through the effect of substituents.

The observed chemical shifts $\delta \mathrm{C}=\mathrm{N}$ (ppm) values have been correlated ${ }^{54-56}$ with Hammett constants and $\mathrm{F}$ and $\mathrm{R}$ parameter the results of statistical analysis are presented in Table-2. From Table-2, it is evident that the $\delta \mathrm{C}=\mathrm{N}$ chemical shifts (ppm) have shown satisfactory correlation with Hammett constants $\sigma^{+}$ and $\sigma_{\mathrm{I}}$. The remaining Hammett constants $\sigma, \sigma_{\mathrm{R}}, \mathrm{F}$ and $\mathrm{R}$ parameters have shown poor correlation. This is due to the reason stated earlier with resonance conjugative structure shown in Fig-1.In view of inability of some of the $\sigma$ constants to produce individually satisfactory correlation, the authors think that it is worthwhile to seek multiple correlation involving $\sigma_{\mathrm{I}}$ and $\sigma_{\mathrm{R}}, \mathrm{F}$ and $\mathrm{R}$ parameters [57]. This is given the following equations (10) and (11).

$\delta \mathrm{C}=\mathrm{N}(\mathrm{ppm})=160.26( \pm 1.49)-4.19( \pm 1.19) \sigma_{\mathrm{I}}-4.56( \pm 1.18) \sigma_{\mathrm{R}}---(10)$ $(R=0.959, \quad \mathrm{n}=10, \quad \mathrm{P}>95 \%)$ $\delta \mathrm{C}=\mathrm{N}(\mathrm{ppm})=159.02( \pm 1.44)-1.86( \pm 0.06) \mathrm{F}-5.61( \pm 1.98) \mathrm{R}---(11)$ $(R=0.958, \quad \mathrm{n}=10, \quad \mathrm{P}>95 \%)$ 
J. Chil. Chem. Soc., 63, № 2 (2018)

Table-3. Antibacterial activity of substituted benzylidene-2-chloro-4-methylanilines.

\begin{tabular}{|c|c|c|c|c|c|c|}
\hline \multirow{2}{*}{ S.No. } & \multirow{2}{*}{ Substituent } & \multicolumn{5}{|c|}{ Zone of Inhibition (mm) } \\
\cline { 3 - 7 } & & \multicolumn{3}{|c|}{ Gram positive Bacteria } & \multicolumn{2}{c|}{ Gram negative Bacteria } \\
\cline { 3 - 7 } & & B.subtilis & M.luteus & S.aureus & E.coli & \multicolumn{2}{c|}{ P.aeruginosa } \\
\hline 1 & $\mathrm{H}$ & 7 & 7 & 8 & 7 & 7 \\
\hline 2 & $4-\mathrm{Br}$ & 9 & 8 & 7 & - & 8 \\
\hline 3 & $2-\mathrm{Cl}$ & 8 & 8 & 7 & 8 & 7 \\
\hline 4 & $3-\mathrm{Cl}$ & 8 & - & - & 7 & 8 \\
\hline 5 & $4-\mathrm{Cl}$ & 7 & 8 & 8 & 8 & 8 \\
\hline 6 & $2-\mathrm{F}$ & - & 8 & 7 & 9 & 9 \\
\hline 7 & $4-\mathrm{Me}$ & 7 & & 10 & 8 & 7 \\
\hline 8 & $2-\mathrm{OMe}$ & 8 & 7 & 8 & 8 & 8 \\
\hline 9 & $4-\mathrm{OMe}$ & 8 & 8 & - & - & 7 \\
\hline 10 & $4-\mathrm{NO}$ & 7 & 7 & 7 & 7 & - \\
\hline
\end{tabular}

Table-4. Antifungal activity of substituted benzylidene-2-chloro-4-methylanilines.

\begin{tabular}{|c|c|c|c|}
\hline \multirow{2}{*}{ S.No. } & \multirow{2}{*}{ Substituent } & \multicolumn{2}{|c|}{ Zone of Inhibition (mm) } \\
\cline { 3 - 4 } & & A.niger & Pen.scup \\
\hline 1 & $\mathrm{H}$ & 7 & 8 \\
\hline 2 & $4-\mathrm{Br}$ & - & 10 \\
\hline 3 & $2-\mathrm{Cl}$ & 8 & 7 \\
\hline 4 & $3-\mathrm{Cl}$ & 8 & 9 \\
\hline 5 & $4-\mathrm{Cl}$ & 7 & 8 \\
\hline 6 & $2-\mathrm{F}$ & 7 & - \\
\hline 7 & $4-\mathrm{Me}$ & - & 8 \\
\hline 8 & $2-\mathrm{OMe}$ & 8 & 7 \\
\hline 9 & $4-\mathrm{OMe}$ & 7 & - \\
\hline 10 & $4-\mathrm{NO} 2$ & 13 & 14 \\
\hline & MICONAZOLE & - & - \\
\hline
\end{tabular}

\section{Microbial activities}

Imine derivatives possess a wide range of biological activities ${ }^{1,2,13,15-20}$. These multipronged activities are associated with different substituents and the unsaturation of $\mathrm{C}=\mathrm{N}$ moiety in between the aryl rings. Hence, it is intended to examine their antimicrobial activities against their respective bacterial and fungal strains.

Antibacterial activities

The in vitro antibacterial activity of the synthesized imine compounds were performed by using Kirby-Bauer ${ }^{52}$ disc diffusion technique. Antibacterial activity was screened against three gram positive bacteria (Staphylococcus aureus, Micrococcous luteusand Bacillus subtilis) and two gram negative bacteria (Pseudomonas aeruginosa and E. coli) by measuring the zone of inhibition on agar plates at the Concentration of $250 \mu \mathrm{g} / \mathrm{mL}$ with Ampicillin taken as the standard drug. The measuring zone of inhibition values are presented in Table- 3 and the corresponding clustered column Chart is shown in Fig-2.

A good antibacterial activity has been possessed by all substituents on the microorganisms in general. The substituent 4- $\mathrm{CH}_{3}$ has shown good antibacterial activity against Staphylococcus aureus. The substituents 2-F and 2-OMe have shown good activity and the remaining substituents have shown moderate activity against Pseudomonas. All the substituents have shown improved antibacterial activity against Bacillus subtilis.

\section{Antifungal activities}

The in vitro antifungal activity of the synthesized imine compounds were performed by using Kirby-Bauer ${ }^{52}$ disc diffusion technique. Antifunga activity was screened against fungi (Aspergillusniger and Pencplium Scup) by measuring the zone of inhibition on PDA agar plates at the Concentration of $250 \mu \mathrm{g} / \mathrm{mL}$ with Miconazole is used as a standard antifungal agent The measuring zone of inhibition values are presented in Table- 4 and the corresponding clustered column Chart is shown in Fig-3. All the substituents have shown moderate antifungal activity against the microorganisms.

\section{CONCLUSIONS}

A series of aryl imines have been synthesized by oxidative coupling of aryl amines and substituted benzaldehydes using microwave irradiation in the presence of $\mathrm{SiO}_{2}-\mathrm{H}_{3} \mathrm{PO}_{4}$ under solvent-free conditions. This reaction protocol offers a simple, eco-friendly, non-hazardous, easier work-up procedure and good yields. These imines are characterized by their physical constants, spectral data. The UV, IR, NMR spectral data of these imines has been correlated with Hammett substituent constants, F and R parameters. From the results of statistical analyses the effects of substituent on the spectral data have been studied. The Antimicrobial activities of all synthesized imines have been studied using Bauer-Kirby method. 


\section{ACKNOWLEDGEMENT}

The authors thank DST NMR Facility Unit, Department of Chemistry, Annamalai University, Annamalainagar - 608002 for recording NMR spectra of compounds.

\section{REFERENCES}

[1] A. S. Shawali, N. M. S. Harb, K. O. Badahdah, J. Heterocycl.Chem. 22, 1397 (1985)

[2] M. Mustapha, B. R. Thorat, S.Sawant, R. G. Atram, R. Yamgar, J. Chem. Pharm. Res. 3(4), 5 (2011).

[3] K. C. Gupta, A. K. Sutar. Co. ord. Chem. Rev. 252, 1420 (2008).

[4] M. Yuan, F. Zhao, W. Zhang, Z. M. Wang, S. Gao, Inorg. Chem. 46, 11235 (2007).

[5] H. Fukuda, K. Amimoto, H. Koyama, T. Kawato, Tetrahedron Lett. 50, 5376 (2009)

[6] Y.C. Liu, C.Y. Yang, Inorg. Chem. Commun., 12, 704 (2009).

[7] A. C. W. Leung, M. J. Mac Lachlan, J. Inorg. Organomet.Polym.Mater. 17, 57 (2007).

[8] W. Zishen, L. Zhiping, Y. Zhenhuan Transit. Met. Chem. 18291 (1993).

[9] K. Nejati, Z. Rezvani, B. Massoumi, Dyes Pigment. 75653 (2007).

[10] E. Naderi, A. H. Jafari, M. Ehteshamzadeh, M.G. Hosseini, Met. Chem. Phys. 115852 (2006)

[11] D. Sriram, P. Yogeeswari, N.S. Myneedu, V. Saraswati, Bioorg. Med. Chem. Lett. 16, 2127 (2006).

[12] V. Stilinovic, D. Cincic, B. Kaitner, Acta. Chim.Slov. 55, 874 (2008).

[13] V. Tiwari, J. Meshram, P. Ali, Der. Pharm. Chim. 2, 187 (2010).

[14] J.J. Bhatt, B.R. Shah, H.P. Shah, P.B. Trivedi, N.K. Undavia, N.C. Desai, Indian. J. Chem. 33B, 189 (1994).

[15] A. A. Bakibaev, V. K. Gorshkova, O. V. Arbit, V. D. Filimonov, A. S. Saratikov, Pharm. Chem. J. 31, 53 (1997)

[16] R.B. Patel, P.S. Desai, K.R. Desai, K.H. Chikhalia, Indian J. Chem. 45B, 773 (2006).

[17] S. Kantevari, T. Yempala, P. Yogeswari, D. Sriram, B. Sridhar, Bioorg. Med. Chem. Lett. 15, 4316 (2011).

[18] A. Kundu, N. A. Shakil, D. B. Saxena, J. Pankaj Kumar and S. Walia, J. Env. Sci. Health. 44B 428 (2000)

[19] R. Yadav, S.D. Srivastava, S.K. Srivastava, Indian. J. Chem. 44B, 1262 (2005).

[20] R. T. McBurney, P. C. Fernando, J. C. Walton, RSC Adv. 12, 1264 (2012).

[21] M. Adib, E. Sheibani, H. R. Bijanzadeh, L. G. Zhu, Tetrahedron. 64, 10681 (2008)

[22] A. K. Chakraborti, S. Bhagat, S. Rudrawar, Tetrahedron Lett. 45, 7641 (2004).

[23] M. Movrin, D. Maysinger, Pharmaize, 34, 535 (1979).

[24] J. Barluenga, J. A. Agustin, F. Aznar, C. Valdes, J. Am. Chem. Soc. 131, 4031 (2009).

[25] D. Bandyophayay, S. Mukherjee, R. R. Rodriguez, B. K. Banik. Molecules, 15, 4207 (2010).

[26] S. K. Samanta, I.Kylanlathi and J. Y. Kauhaluoma, Bioorg. Med. Chem. Lett. 15, 3717 (2005)

[27] A. Lumbroso, F. Chevillier, I. Beaudet, T. Bessan, E. L. Grognet, Tetrahedron. 659180 (2009).

[28] H. J. conn, "A Handbook on the Nature and Uses of the Dyes Employed in the Biological Laboratory" SIXTH EDITION, THE WILLIAMS \& WILKINS COMPANY, Baltimore 2, (1953) Maryland, USA.

[29] B. D. Mather, K. Viswanathan, K. M. Miller, T. E. Long., Prog. Polym. Sci. 31, 487 (2006).

[30] S. F. Martin, Pure Appl. Chem. 81, 195(2009).

[31] A. C. Dash, B. Dash, D. Panda, J. Org. Chem. 50, 2905 (1985).

[32] J. H. Xie, S. F. Zhu, Q. L. Zhou, Chem. Rev. 111, 1731(2011).

[33] S. E. Denmark, G. L. Beutner, Angew. Chem. Int. Ed. 47, 1560 (2008).

[34] A. Suares, C. W. Downey, G. C. Fu, J. Am. Chem. Soc. 127, 11244 (2005).

[35] S. France, M. H. Shah, A. Weatherwax, H. Wack, J. P. Roth, T. Lectka, J. Am. Chem. Soc. 127, 1206 (2005).

[36] W. Chang, B. J. Ahn, J. Ind. Engg. Chem. 10, 690 (2004).

[37] M. Abid, M. Savolainen, S.Landge, J. Hu, G. K. Suryaprakash, G. A. Olah, B. Torok, J. Fluo. Chem. 128, 587 (2007)

[38] D. A. Barr, G. Donegn, R. Grigg, J. Chem. Soc., Perkin Trans. 1, 1550 (1989).
[39] L. Blackburn, R. J. K. Taylor, Org. Lett. 3, 1637 (2001).

[40] M. Gopalakrishnan, P. Sureshkumar, V. Kanagarajan, J. Thanusu, Res. Chem. Inter. med. 33, 541 (2007).

[41] R. S. Varama, Green Chem. (1999) 43

[42] G. Dutheuil, S. C. Bonnaire, X. Pannecoucke, Angew. Chem. Int. Ed. Engl 46, 1290 (2007).

[43] B. H. Lipshutz, H. Shimizu, Angew. Chem. Int. Ed. 432228 (2004)

[44] E. Ali, M. R. N. Jamal, Efficient synthesis of imines by MCM-41-SO 3 nanaocatalyst. No. A006, $14^{\text {th }}$ international Conference on synthetic organic chemistry, (ESCOC-14), 1 (2010).

[45] A. Hasaninejad, A. Zare, H. Sharghi, M. Shekouhy, Arkicov. 11, 64 (2008).

[46] H. Zhanag, S. Syed, C. F. Barbas, Org. Lett. 12,708 (2010)

[47] C. M. Bode, A. Ting, S. E. A. Schaus, Tetrahedron. 62, 11499 (2006).

[48] M. A. Vazquez, M. Landa, L. Reyes, M. J. Tamariz, D. Francisco, Synth. Commun. 34, 2705 (2004)

[49] M. Hudlicky, Oxidations in Organic Chemistry, ACS Monograph series, ACS, Washington, DC, (1990)

[50] S. M. Landge, V. Atanassova, M.Thimmaiah, B. Torok, Tetrahedron Lett. 48, 5161 (2007).

[51] G. Thirunarayanan, .Iup. J. Chem. 3(4), 35 (2010).

52. A. W. Bauer, W. M. M. Kirby, J. C Sherris, M. Truck, Am. J. Clin. Pathol. 45, 493 (1996).

[53] K. Sathiyamoorthi, V. Mala, S.P. Sakthinathan, D. Kamalakkannan, R. Suresh, G. Vanangamudi, G. Thirunarayanan Spectrochimica Acta, 112A, 245 (2013)

[54] (a). S. P. Sakthinathan, G. Vanangamudi, G. Thirunarayanan Spectrochimica Acta 95A, 693 (2012). (b). G. Thirunarayanan, G. Vanangamudi, Spectrochimica Acta 81A, 390 (2011). (c) G. Thirunarayanan, M. Gopalakrishnan, G.Vanangamudi, Spectrochimica Acta 67(A), 1106 (2007).

[55] B.Z`. Jovanovic', A.D. Marinkovic', F.H. Assaleh, J. Csana'd, J. Mol. Str. 744 (2005)

[56] S. Ž. Drmanić, A. D. Marinković, J. B. Nikolić, B. Jovanović, J. Serb. Chem. Soci. 77, 1 (2012).

[57] C. G. Swain, E. C. Lupton, J.Amer. Chem. Soc., 90, 4328 (1968). 